\title{
DeVelopment of A Protein-free Chemically defined CULtURe medium FOR THE PROPAGATION OF the OYSTER PATHOGEN PERKINSUS MARINUS
}

\author{
LA PEYRE J.F.* \& FAISAL M.*
}

\begin{abstract}
Summary :
In the present study we describe a protein-free, chemically defined culture medium, designated JL-ODRP-3, which supports the propagation of Perkinsus marinus, a parasite of the eastern oyster, Crassostrea virginica. P. marinus adapted rapidly to the defined medium and the growth rate of the protozoan increased significantly following a few subcultures. Two isolates of P. marinus, one from the Chesapeake Bay (Virginia) and the other from the Gulf of Mexico (Texas) were cultured for at least ten passes. The doubling times for the isolates from Virginia and Texas, in $\log$ phase, were $18 \pm 1.2$ and $28.6 \pm 3.2$ hours respectively, after ten passes in JL-ODRP-3. Moreover, P. marinus cells cultured in the defined medium were infective to eastern oysters. Finally, the defined medium was used successfully to initiate continuous cultures of $P$. marinus from heart fragments of infected oysters. The absence of proteins and peptides from this chemically defined medium demarcates JL-ODRP-3 as the most suitable medium to study $P$. marinus proteins, to produce antigens for antibody production, and to screen chemotherapeutic agents.
\end{abstract}

KEY WORDS : Perkinsus marinus, protozoan, in vitro, protein-free chemically defined culture medium, oyster parasite, Crassostrea virginica.

MOTS CLÉS : Perkinsus marinus, protozoaire, in vitro, milieu de culture défini et sans protéine, parasite d'huitre, Crassostrea virginica
Résumé : Développement d'Un milieu de Culture sans protérne et DE COMPOSITION DÉFINIE POUR LA PROPAGATION D'UN PATHOGĖNE D'huitre, Perkinsus marinus (APICOMPleXa)

Dans cette étude, nous avons décrit un milieu de culture, désigné JL-ODRP-3, sans protéine et dont la composition est définie, qui permet la propagation de Perkinsus marinus, un parasite de l'huitre américaine, Crassostrea virginica. Perkinsus marinus s'est adapté rapidement à ce milieu de culture défini et le taux de prolifération de ce protozoaire a augmenté d'une manière significative suite à quelques sous-cultures. Deux isolats de P. marinus, I'un de la baie de Chesapeake (Virginie) et l'autre du golfe du Mexique (Texas) ont été cultivés et repiqués au moins dix fois en sous-culture. Les temps de générations pour les isolats de Virginie et du Texas, en croissance logarithmique, étaient de $18 \pm 1,2$ et de 28,6 $\pm 3,2$ heures respectivement, après dix passages dans le milieu de culture JL-ODRP-3. Des cellules de P. marinus cultivées dans le milieu défini étaient capable d'infecter des huitres américaines. Finalement, le milieu défini a été utilisé pour l'initiation de cultures continues de P. marinus à partir de fragments de coeurs d'huitres infectées. L'absence de protéines et de peptides dans ce milieu défini présente JL-ODRP-3 comme le milieu le plus propice à l'étude des protéines de $P$. marinus, à la production d'antigènes pour la création d'anticorps, et à la détection d'effets d'agents chémothérapeutiques.

\section{INTRODUCTION}

1 he protozoan Perkinsus marinus causes heavy losses in oyster populations of the Atlantic and Gulf coasts of the United States (reviewed in Burreson and Calvo, 1996; Ford, 1996; Soniat, 1996). This oyster pathogen was discovered in the Gulf of Mexico in 1948 (Mackin et al., 1950) and named Dermocystidium marinum as it was thought to be a fungus. Since Perkins (1976) showed that the motile stage of $P$. marinus, the zoospore, contained an apical complex, the parasite was renamed and included in the phylum Apicomplexa (Levine, 1978).

Following four decades of trials to culture P. marinus, it was recently demonstrated that $P$. marinus could be

\footnotetext{
* School of Marine Science, Virginia Institute of Marine Science, College of William and Mary, Gloucester Point, Virginia 23062. Correspondence: Dr. Jerome La Peyre.
}

Tel : (804) 642-7231 - Fax : (804) 642-7186 - Email: jlap@vims.edu propagated in vitro (reviewed in La Peyre, 1996). The culture medium used for the first isolation of $P$. marinus, JL-ODRP-1, consisted of more than 60 ingredients combined to resemble the known composition, osmolality, and $\mathrm{pH}$ of plasma of bivalve mollusks (La Peyre et al., 1993). This medium was supplemented with purified fraction $\mathrm{V}$ of bovine serum albumin (BSA), cod liver oil, and yeastolate ultrafiltrate $(10 \mathrm{kDa})$. The use of animal serum was avoided to eliminate the effects of undefined complex mixtures on $P$. marinus (Barnes and Sato, 1980; Maurer, 1992). In order to identify and purify proteins of $P$. marinus, BSA was eliminated from JL-ODRP-1 and culture conditions were optimized (La Peyre and Faisal, 1996). Using this protein deficient medium, multiple parasite extracellular proteins including serine proteases were identified ( $\mathrm{La}$ Peyre et al., 1995).

The BSA-free JL-ODRP-1 medium, however, contains the undefined ingredients yeastolate and cod liver oil, 
both of which could interfere with a variety of experiments. For example, peptides in the yeastolate ultrafiltrate can potentially inhibit the uptake of certain chemotherapeutic agents (Kerridge and Vanden Bossche, 1990). The presence of yeastolate ultrafiltrate in the culture medium has also induced polyclonal mitogenesis in mouse splenocytes, thus interfering with the development of monoclonal antibodies against $P$. marinus extracellular proteins (Faisal et al., 1996). In this study we report the composition of the protein-free, chemically defined culture medium, JL-ORDP-3. We also provide evidence that JL-ORDP-3 supports the propagation of established $P$. marinus cell lines, is suitable for the initiation of primary cultures of $P$. marinus from naturally infected oysters, and that following many subcultures in this medium, $P$. marinus remains infective to eastern oysters.

\section{MATERIALS AND METHODS}

\section{MODIFICATIONS}

OF THE CULTURE MEDIUM JL-ORDP-1

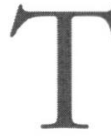

he protein-free chemically defined medium was modified from JL-ORDP-1 medium (La Peyre et al., 1993) by elimination of BSA, yeastolate ultrafiltrate and cod liver oil, by increasing the amino acid and vitamin concentrations and by adding a chemically defined lipid solution and vitamin $\mathrm{B}_{12}$. A detailed procedure to prepare this chemically defined medium, designated JL-ORDP-3, is provided below and its final composition is given in Table I. The $\mathrm{pH}$ of the chemically defined medium was 7.4 and osmolality was $754( \pm 4) \mathrm{mOsm} / \mathrm{kg}$ as measured with a 5,500 vapor pressure osmometer (Wescor Inc., Logan, UT). No adjustment in the $\mathrm{pH}$ or osmolality of JLORDP-3 was necessary.

\begin{tabular}{lcc}
\hline \multicolumn{1}{c}{ Ingredients } & mg/L & Source \\
\hline Major inorganic salts and buffers & & \\
Calcium Chloride Anhydrous & 199.8 & $\mathrm{~S}$ \\
Magnesium sulfate Anhydrous & $3,371.3$ & $\mathrm{~S}$ \\
Magnesium Chloride Anhydrous & $2,031.3$ & $\mathrm{~S}$ \\
Potassium Chloride & 574.6 & $\mathrm{~S}$ \\
Sodium Chloride & $15,973.3$ & $\mathrm{~S}$ \\
Sodium Bicarbonate & $2,000.0$ & $\mathrm{~S}$ \\
HEPES & $5,957.5$ & $\mathrm{~S}$ \\
Trace elements & & \\
Boric acid & 0.4 & $\mathrm{~S}$ \\
Sodium Bromide & 0.686 & $\mathrm{~S}$ \\
Sodium Fluoride & 0.2799 & $\mathrm{~S}$ \\
Strontium Chloride $\mathrm{Hexahydra}$ & 17.77 & $\mathrm{~S}$ \\
Cupric Sulfate $7 \mathrm{H}_{2} \mathrm{O}$ & 0.00249 & $\mathrm{~S}$ \\
Ferrous Sulfate $5 \mathrm{H}_{2} \mathrm{O}$ & 0.834 & $\mathrm{~S}$ \\
Zinc Sulfate $7 \mathrm{H}_{2} \mathrm{O}$ & 0.1438 & $\mathrm{~S}$ \\
Manganese Sulfate $\mathrm{H}_{2} \mathrm{O}$ & 0.0000338 & $\mathrm{G}$ \\
& & \\
\hline
\end{tabular}

Sodium Metasilicate $9 \mathrm{H}_{2} \mathrm{O}$

Molybdic Acid $4 \mathrm{H}_{2} \mathrm{O}$ (Ammonium)

Ammonium Metavanadate

Nickel Chloride $6 \mathrm{H}_{2} \mathrm{O}$

Stannous Chloride $9 \mathrm{H}_{2} \mathrm{O}$

Amino Acids

L-Arginine . $\mathrm{HCl}$

L-Cystine

L-Glutamine

L-Histidine $\mathrm{HCl} \mathrm{H}_{2} \mathrm{O}$

L-Leucine

L-Isoleucine

L-Lysine HCI

L-Methionine

L-Phenylalanine

L-Threonine

L-Tryptophan

L-Tyrosine

L-Valine

L-Alamine

L-Asparagine $\mathrm{H}_{2} \mathrm{O}$

L-Glutamic Acid

L-Glycine

L-Proline

L-Serine

Taurine

\section{Carbohydrates}

Glucose

Galactose

Trehalose

Nucleic Acid Precursors

Adenosine 5'-Monophosphate

Cytidine $5^{\prime}$-Monophosphate

Uridine 5'-Triphosphate

\section{Vitamins}

D-Ca Pantothenate

Choline Chloride

Folic Acid

i-Inositol

Niacinamide

P-AminoBenzoic Acid

D-Pantothenic Acid

Pyridoxin $\mathrm{HCl}$

Riboflavin

Thiamine $\mathrm{HCl}$

Vitamin B-12

Lipids

Arachidonic Acid

Cholesterol

DL-a-Tocopherol-Acetate

Linoleic Acid

Linolenic Acid

Myristic Acid

Oleic Acid

Palmitric Acid

Palmitic Acid

Stearic Acid

\section{Miscellaneous}

Coenzyme A

Chloramphenicol

Ethyl alcohol

Pluronic ${ }^{\circledR 8}$ F-68

Tween 80
L-Asparctic Acid

Phenol Red

0.0284
0.0000248
0.000117
0.0000238
0.0000226

\section{2}

12.0

50.0

21.0

26.2

26.26

36.26

7.56

16.5

23.8

3.1

18.0

23.4

108.9

15.0

13.3

14.7

57.5

11.5

60.5

150.0

500.0

100.0

100.0

G

G

G

G

G

G

G

G

G

G

G

G

G

G

G

G

G

G

1.0

1.0

1.0

0.4

3.0

2.0

35.0

2.0

2.0

0.5

2.0

0.4

2.0

0.01

0.07

* Source of ingredients: $\mathrm{G}=$ Gibco laboratories, Grand Island, NY; $\mathrm{S}=$ Sigma Chemical Co., St Louis, MO.

Table I. - Composition of the medium JL-ORDP-3. Osmolality $756 \mathrm{mOsm} / \mathrm{Kg}, \mathrm{pH} 7.4$. 
PROCEDURE TO CONSTITUTE THE PROTEIN-FREE CHEMICALLY DEFINED MEDIUM JL-ORDP-3

All chemicals used were tissue culture grade reagents purchased from Sigma Chemical Co. (St. Louis, MO) unless otherwise indicated. A basal salt solution (BSS) was first prepared by dissolving $22 \mathrm{~g}$ of Seawater Synthetic Basal Salt Mixture and $2 \mathrm{~g}$ sodium bicarbonate in a final volume of $912 \mathrm{ml}$ of culture grade water (Milli-Q UF water purification system, Millipore Co. Bedford, MA). Potassium chloride $(0.1772 \mathrm{~g})$ was added to maintain a $\mathrm{Na}^{+} / \mathrm{K}^{+}$ratio of 23 . The BSS solution was then filtered $(0.22 \mu \mathrm{m})$ sterilized. HEPÈS ( $25 \mathrm{ml}$ of a $1 \mathrm{M}$ solution) was added for buffering at a $5 \% \mathrm{CO}_{2}$ atmosphere. The following solutions were then added to BSS under sterile conditions:

1) $2 \mathrm{ml}$ of Trace Element Mix (Gibco BRL, Grand Island, NY),

2) $1 \mathrm{ml}$ of a solution containing $0.834 \mathrm{mg} / \mathrm{ml}$ of ferrous sulfate and $0.143 \mathrm{mg} / \mathrm{ml}$ of zinc sulfate,

3) $1 \mathrm{ml}$ of a solution containing $0.249 \mathrm{mg} / \mathrm{ml}$ of cupric sulfate,

4) $10 \mathrm{ml}$ of MEM Amino Acids Solution without glutamine (Gibco BRL),

5) $10 \mathrm{ml}$ of MEM Non-Essential Amino Acids Solution (Gibco BRL),

6) $10 \mathrm{ml}$ of a solution containing $10 \mathrm{mg} / \mathrm{ml}$ of alanine, $5 \mathrm{mg} / \mathrm{ml}$ of glycine, $5 \mathrm{mg} / \mathrm{ml}$ serine, $15 \mathrm{mg} / \mathrm{ml}$ taurine and $5 \mathrm{mg} / \mathrm{L}$ glutamine,

7) $6 \mathrm{ml}$ of RPMI 1640 Vitamin Solution,

8) $10 \mathrm{ml}$ of a carbohydrate solution containing $50 \mathrm{mg} / \mathrm{ml}$ of glucose, $10 \mathrm{mg} / \mathrm{ml}$ of trehalose, and $10 \mathrm{mg} / \mathrm{ml}$ of galactose,

9) $10 \mathrm{ml}$ of Chemically Defined Lipid Concentrate (Gibco BRL),

10) $2 \mathrm{ml}$ of a solution containing $0.5 \mathrm{mg} / \mathrm{ml}$ each of adenosine $5^{\prime}$-monophosphate, cytidine $5^{\prime}$-monophosphate, uridine $5^{\prime}$-triphosphate and coenzyme A,

11) $10 \mathrm{ml}$ of a solution containing $0.5 \mathrm{mg} / \mathrm{ml}$ of chloramphenicol,

12) $1 \mathrm{ml}$ of Phenol red solution (Gibco BRL).

\section{DETERMINATION OF THE CAPABILITY}

OF JL-ORDP-3 TO SUPPORT THE PROPAGATION

OF ESTABLISHED $P$. MARINUS CELL LINES

Two isolates of Perkinsus marinus, Perkinsus-1 and LMTX-1, were used to demonstrate the capability of JLORDP-3 to support their propagation in vitro. Perkinsus1 is the first isolate of $P$. marinus to be succesfully propagated in vitro. This cloned and fully characterized isolate of $P$. marinus was obtained from the heart of an infected oyster from the lower Chesapeake Bay, in February of 1992, and has been subcultured every two to four weeks in JL-ORDP-1 medium (La Peyre et al., 1993). The medium JL-ORDP-1 was slightly modified and contained $4 \mathrm{mg} / \mathrm{ml}$ instead of $12 \mathrm{mg} / \mathrm{ml}$ of BSA after June 1993. The isolate LMTX-1 was kindly provided by Dr. Dave Bushek (Belle W. Baruch Institute of Marine Biology and Coastal Research, University of South Carolina) in June 1994. Culture of LMTX-1 was initiated in July 1993 from hypnospores of an infected oyster collected in Laguna Madre, Texas using a technique described by La Peyre and Faisal (1995), Bushek (1994). This isolate has also been propagated in JL-ORDP-1. Division of both isolates propagated in JL-ORDP-1 medium is by schizogony.

Stock cultures of Perkinsus-1 and LMTX-1 were propagated in $75 \mathrm{~cm}^{2}$ flasks (Corning Glassworks, Corning, $\mathrm{NY})$ using the JL-ORDP-1 medium ( $50 \mathrm{ml} /$ flask) at a seeding density of $10^{6} / \mathrm{ml}$, and subcultured every four weeks. All culture flasks were maintained at $28{ }^{\circ} \mathrm{C}$ in a humidified chamber in the presence of $5 \% \mathrm{CO}_{2}$ tension.

Perkinsus marinus cells were harvested from stock cultures in JL-ORDP-1 and rinsed three times in either JLORDP-1 or JL-ORDP-3 medium. Cells were then resuspended in $50 \mathrm{ml}$ of either medium in triplicate $75 \mathrm{~cm}^{2}$ culture flasks at a seeding density of $2 \times 10^{5}$ cells $/ \mathrm{ml}$. Samples $(1.5 \mathrm{ml} /$ flask $)$ of cultured media were collected on days one, three, five, seven, nine, twelve and fifteen for cell counts with a Bright-line hemacytometer (Reichert, Buffalo, NY). Cell clumps arising from division of the schizonts were disaggregated by three passages through a 25 -gauge needle prior to counting. The viability of the cells was determined by staining with $0.005 \%$ of neutral red.

The growth of $P$. marinus cells in JL-ORDP- 3 medium during the first subculture was compared to growth in JL-ORDP-1. Perkinsus marinus cells in each medium were then subcultured every three weeks and their growth was followed for the first three consecutive subcultures (i.e., $2^{\text {nd }}$ to $4^{\text {th }}$ subculture) and at the eleventh subculture as previously described.

\section{INFECTION OF OYSTERS WITH P. MARINUS CELLS PROPAGATED IN JL-ORDP-3}

To determine whether $P$. marinus would retain its infectivity to eastern oysters following several subcultures in the chemically defined medium, P. marinusfree oysters (Pemaquid Oyster Co., Waldoboro, Maine) were experimentally infected with cultured cells. Perkinsus-1 cells propagated in JL-ORDP-3 ( $18^{\text {th }}$ subculture) were harvested, resuspendend at a density of $10^{7} \mathrm{cells} / \mathrm{ml}$ of an iso-osmotic salt solution (27 ppt, 750 mOsm, Forty Fathoms marine mix, Marine Enterprises Inc., Baltimore, MD) and $100 \mu \mathrm{l}$ of this suspension injected into the mantle cavity of 25 notched oysters. After 14 days, oysters received a second dose of Perkinsus-1 ( $10^{6}$ cells/oyster). Control oysters (25) received the same regimen of a salt solution. Each oyster group was maintained in an aerated 80 liter tank 
at $28{ }^{\circ} \mathrm{C}$. The water was changed weekly with $1 \mu \mathrm{m}$ filtered estuarine water (York River, Gloucester point, VA) adjusted to $27 \mathrm{ppt}$ with Forty Fathoms marine mix salts. The oysters were not fed to avoid the introduction of extraneous $P$. marinus cells via algae.

Forty-two days post-infection, the presence of $P$. marinus cells in both oyster groups was determined in the rectal, gill and mantle tissue of each individual oyster using the Ray's Test (Ray, 1952). The intensity of infection in each oyster was rated according to the categories of Ray (1954) by estimating the percentage of tissue occupied by the parasite.

\section{SUITABILITY OF JL-ORDP-3}

TO SUPPORT PRIMARY CULTURES OF $P$. MARINUS FROM NATURALLY INFECTED OYSTERS

Perkinsus marinus-infected eastern oysters were collected from Wreck Shoal, James River (VA). Cultures of $P$. marinus were initiated from the heart fragments of ten infected oysters according to the procedure described in La Peyre et al. (1993). Briefly, the heart from each oyster was removed aseptically, rinsed in a concentrated antibiotic solution and finely minced with a razor blade. The heart fragments were then washed five times in a sterile filtered $(0.2 \mu \mathrm{m})$ salt solution, resuspended in JL-ORDP-3 medium, and placed in $25 \mathrm{~cm}^{2}$ culture flasks. The cultures were incubated at $28{ }^{\circ} \mathrm{C}$ in the presence of $5 \% \mathrm{CO}_{2}$ atmosphere. Propagation of $P$. marinus was monitored using an Olympus (CK-2) inverted light microscope with phase contrast optics at a magnification of $200 \times$. After three weeks of incubation, subculturing was attempted.

\section{STATISTICAL ANALYSIS}

Growth rate was expressed as doubling time (i.e., the time for a population to double in number) during log phase. In this study, log phase was defined as the period of maximum increase in cell number between two sampling time. Doubling time data was $\log _{10}$ transformed and compared by one factor analysis of variance followed by SNK's multiple comparisons of means when significant differences $(p<0.05)$ were found.

\section{RESULTS}

\section{Propagation of $P$. MarinUs Established} CELL LINES IN JL-ORDP-3

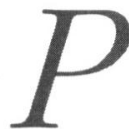
erkinsus- 1 cells proliferated in JL-ORDP-3 following their transfer from JL-ORDP-1 medium, however, the growth rate in JL-ORDP-3 was significantly lower than that of the same stock of cells grown in JL-ORDP-1 (Fig. 1). The doubling time

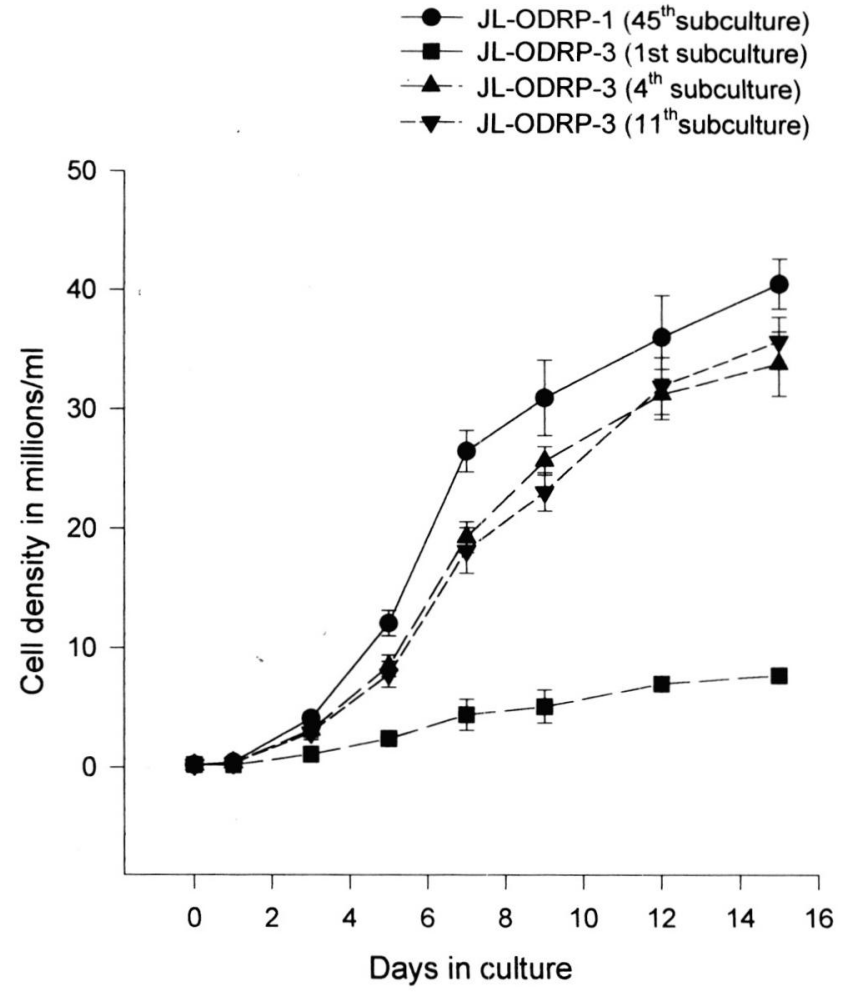

Fig. 1. - Propagation of Perkinsus-1 in JL-ORDP-1 ( $48^{\text {th }}$ subculture) and in JL-ORDP-3 media $\left(1^{\text {st }}, 4^{\text {th }}\right.$ and $11^{\text {th }}$ subcultures following transfer from JL-ORDP-1). Culture flasks $(\mathrm{N}=3)$ were seeded with $2 \times 10^{5}$ cells $/ \mathrm{ml}$ and were incubated at $28^{\circ} \mathrm{C}$ under $5 \% \mathrm{CO}_{2}$ tension.

for Perkinsus-1 cells in JL-ORDP-3 was about $22 \pm 1.4$ hours which is significantly greater than that of cells cultured in JL-ORDP-1 (i.e., $15 \pm 0.8$ hours, Table II). Viability of Perkinsus-1 cells in defined medium after the initial transfer from JL-ORDP-1 was always $>95 \%$. The growth rate of Perkinsus-1 increased between the first and second subculture and did not significantly change after 11 subcultures (Fig. 1, Table II).

The medium JL-ORDP-3 also sustained the propagation of LMTX-1 cells after a period of adaptation. Cells of LMTX-1 did not initially multiply following their transfer and their viability was reduced to $78 \%$. LMTX-1 required a longer time to adapt to JL-ORDP-3. The growth rate increased progressively from the second to the eleventh subculture (Fig. 2, Table II). The viability of cultured LMTX-1 cells after the $11^{\text {th }}$ subculture rose to $>95 \%$.

\section{MORPHOLOGY OF P. MARINUS IN JL-ORDP-3}

Microscopical examination of Perkinsus-1 and LMTX-1 cells cultured in JL-ORDP-3 medium revealed that their morphology was alike the reported morphology of P. marinus observed either in vivo or freshly isolated 


\begin{tabular}{cccc}
\hline \multicolumn{1}{c}{ Isolate } & Medium & Subculture & Doubling time* $(\mathbf{h})$ \\
\hline Perkinsus-1 & JL-ODRP-1 & $45^{\text {th }}$ & $15.0 \pm 0.8$ \\
& JL-ORDP-3 & $1^{\text {st }}$ & $22.3 \pm 1.4$ \\
& $2^{\text {nd }}$ & $17.1 \pm 2.4$ \\
& $3^{\text {rd }}$ & $16.5 \pm 1.3$ \\
& $4^{\text {th }}$ & $16.9 \pm 1.6$ \\
& $11^{\text {th }}$ & $18.0 \pm 1.2$ \\
LMTX-1 & & \\
& & $16^{\text {th }}$ & $23.8 \pm 3.2$ \\
& JL-ORDP-1 & $1^{\text {st }}$ & $n p^{* * *}$ \\
& JL-ODRP-3 & $2^{\text {nd }}$ & $50.4 \pm 3.6$ \\
& & $3^{\text {rd }}$ & $35.3 \pm 7.4$ \\
& $4^{\text {th }}$ & $37.1 \pm 4.1$ \\
& & $1^{\text {th }}$ & $28.6 \pm 3.2$ \\
\end{tabular}

* Calculated during log phase

** np indicates no propagation.

Table II. - Doubling times of Perkinsus-1 and LMTX-1 cells subcultured in JL-ORDP-1 and in the protein-free defined medium JL-ORDP-3. Cells were seeded into $50 \mathrm{~cm}^{2}$ flasks at a density of $2 \times 10^{5} \mathrm{cells} / \mathrm{ml}$

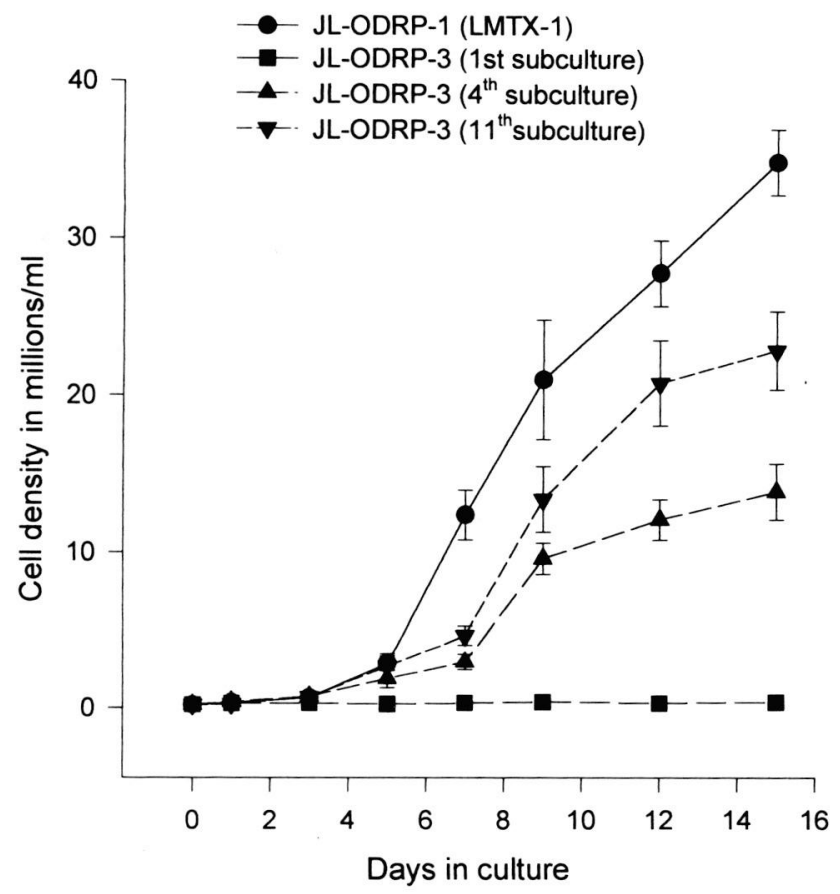

Fig. 2 - Propagation of LMTX-1 in JL-ORDP-1 and in JL-ORDP-3 media $\left(1^{\text {st, }} 4^{\text {th }}\right.$ and $11^{\text {th }}$ subcultures following transfer from JL-ORDP1). Culture flasks $(\mathrm{N}=3)$ were seeded with $2 \times 10^{5}$ cells $/ \mathrm{ml}$ and were incubated at $28^{\circ} \mathrm{C}$ under $5 \% \mathrm{CO}_{2}$ tension.

from infected oysters (Mackin et al., 1950; Perkins, 1969, 1976; La Peyre and Chu, 1994). The smaller cells were about $2-5 \mu \mathrm{m}$ in diameter and exhibited the typical prominent refractile bodies of merozoites (Fig. 3A). Some of the cells enlarged to about 15 to $30 \mu \mathrm{m}$ (Fig. 3B), acquired a vacuole, and divided by schizogony releasing the smaller cells (Fig. 3C). Other cells in the same culture flask appeared to divide by binary fission (Fig. 4A \& B). Since examination of doublet cells revealed that the cell wall of the original mother cell frequently ringed the daughter cells (Fig. 4C), the apparent binary fission was in fact schizogony.

\section{INFECTION OF OYSTERS WITH $P$. MARINUS CELLS PROPAGATED IN JL-ORDP-3}

The prevalence of $P$. marinus in oysters challenged with cells cultured in JL-ORDP-3 was $100 \%$. Twenty one oysters developed light infection while four oysters developed moderate infection as defined by Ray (1954). No P. marinus infection was detected in control oysters.

\section{INITIATION OF PRIMARY CULTURES} OF $P$. MARINUS FROM INFECTED OYSTERS USING JL-ORDP-3

Perkinsus marinus isolated from infected heart fragments propagated in the defined medium. During the first three weeks of primary culture, protozoal cells showed the typical morphology of $P$. marinus, enlarged, and divided by schizogony. Subculturing was attempted at a density of $10^{6}$ cells $/ \mathrm{ml}$ and continuous growth were obtained from eight out of ten oysters. The remaining heart cells did not divide and were diluted out after a few subcultures.

\section{DISCUSSION}

$P$ erkinsus marinus could be propagated in the protein-free culture medium JL-ORDP-3. It was important to subculture P. marinus cells for at least eleven passages in JL-ORDP-3 medium in order to eliminate low concentrations of chemical ingredients that may have been taken up by the cells while growing in JL-ORDP-1 and, to acclimate protozoal cells to the new medium. As our results demonstrate, JL-ORDP-3 supported the continuous growth of two P. marinus isolated through at least ten subcultures. The growth rates measured for both $P$. marinus isolates, Perkinsus-1 and LMTX-1, in the defined medium were lower than in the original medium JLORDP-1, however their doubling times were within the range reported for $P$. marinus grown in protein supplemented media (Gauthier and Vasta, 1995; Dungan and Hamilton, 1995). The decreased growth rates can be attributed to the absence of proteins, peptides, and possibly growth factors that may have been present in the original medium undefined components. Our previous studies have demonstrated that proteins present in JLORDP-1 medium were consumed by $P$. marinus (La Peyre and Faisal, 1995) that produces multiple serine proteases (La Peyre et al., 1995). 

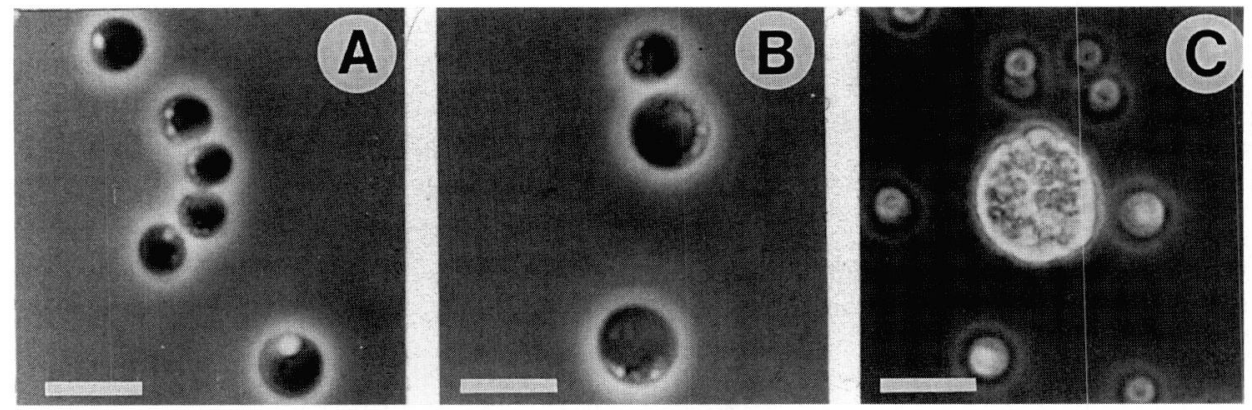

Fig. 3. - Light micrographs of Perkinsus-1 and LMTX-1 cells after $11^{\text {th }}$ subculture in JL-ORDP-3 medium. Flasks were seeded with $2 \times 10^{5}$ cells $/ \mathrm{ml}$ and maintained at $28^{\circ} \mathrm{C}$ under $5 \% \mathrm{CO}_{2}$. A) small-sized Perkinsus- 1 cells : notice the refractile lipid bodies (bar $\left.=10 \mu \mathrm{m}\right)$; B) larger Perkinsus-1 cells with clear vacuole (bar $=10 \mu \mathrm{m})$; C) enlarged LMTX-1 cell dividing by schizogony $($ bar $=25 \mu \mathrm{m})$.
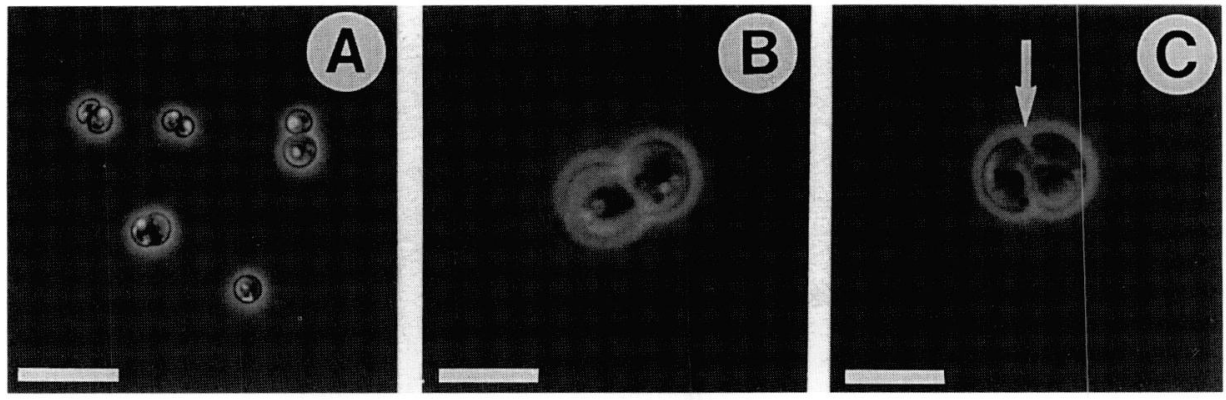

Fig. 4. - Light micrographs of Perkinsus -1 cells after $17^{\text {th }}$ subculture in JL-ORDP-3 medium. Flasks were seeded with $2 \times 10^{5}$ cells $/ \mathrm{ml}$ and maintained at $28^{\circ} \mathrm{C}$ in $5 \% \mathrm{CO}_{2}$ for one week prior to photographing. A) Perkinsus-1 mother cells yielding two daughter cells (bar $=25 \mu \mathrm{m}$ ); B) Perkinsus-1 mother cell dividing (bar $=10 \mu \mathrm{m}$ ); C) cell wall (arrow) of a mother cell following division by schizogony which yielded two daughter cells $(\mathrm{bar}=10 \mu \mathrm{m})$.

The morphology of Perkinsus-1 and LMTX-1 cells in JL-ORDP-3 was similar to the morphology of $P$. marinus observed either in vivo or freshly isolated from infected oysters (Mackin et al., 1950; Perkins, 1969, 1976; La Peyre and Chu, 1994). The size of the smaller cells (i.e., 3-6 $\mu \mathrm{m}$ ) was identical to the size of merozoites isolated from infected oysters by La Peyre and Chu (1994). The small cells had prominent refractile bodies, presumably lipid droplets, like those observed in isolated merozoites. Moreover, the size of the largest dividing cells never exceeded about $30 \mu \mathrm{m}$ which is the size of $P$. marinus schizonts in vivo (Perkins, 1969). On the other hand, cells cultured in JL-ORDP-1 had a much larger size that sometimes exceeded $45 \mu \mathrm{m}$ in diameter (La Peyre et al., 1993). The high protein concentration $(12 \mathrm{mg} / \mathrm{ml} \mathrm{BSA})$ in the original medium JL-ORDP-1 may have caused greater enlargement of cultured cells. Division of $P$. marinus cells of both isolates in JL-ORDP-3 was by schizogony. Mother cells yielded from two to many daughter cells (presumably 4-32).

A defined medium has recently been developed by Gauthier et al. (1995). This medium consists of Dubelcco modified Eagle's medium/Ham's F12 nutrient mixture (1:1) supplemented with $1.7 \mathrm{mg} / \mathrm{ml}$ of fetuin. The major advantage of this medium is its ease of preparation since each component is commercially available. However, fetuin and fetuin breakdown products could interfere with studies on $P$. marinus-derived proteins and peptides. All other commercial media that have been used to culture $P$. marinus were supplemented with fetal bovine serum (FBS, 5-20\%) alone or with oyster plasma (5-20\%) (Gauthier and Vasta, 1993; Kleinshuster and Swink, 1993; Dungan and Hamilton, 1995).

Results of this study clearly demonstrated that despite the absence of proteins, JL-ORDP-3 supported the propagation of $P$. marinus in vitro and the initiation of primary cultures. The propagated cells retained their infectivity and were identical in their morphology to $P$. marinus in vivo. The absence of proteinaceous materials from this chemically defined medium demarcates JL-ORDP-3 as the most suitable medium to study $P$. marinus proteins, to produce antigens for antibody production, and to screen chemotherapeutic agents. Moreover this medium will greatly simplify biochemical, physiological and nutritional studies of P. marinus. 


\section{ACKNOWLEDGEMENTS}

T he authors thank Dr. Leonard Haas for revising the manuscript and Dr. David Bushek for kindly providing the isolate LMTX-1. The research was funded by a grant/cooperative agreement from the National Oceanic and Atmospheric Aministration, Oyster Disease Research Program, grant no. NA26FL0384. The views expressed herein are those of the authors and do not necessarily reflect the views of NOAA or any of its sub-agencies. Virginia Institute of Marine Science contribution No. 2038.

\section{REFERENCES}

Barnes D. \& Sato G. Methods of growth of cultured cells in serum-free medium. Analytical Biochemistry, 1980, 102, 255-270.

Burreson E.M. \& Ragone Calvo L.M. Epizootiology of Perkinsus marinus disease of oysters in Chesapeake Bay, with emphasis on data since 1985. Journal of Shellfish Research, 1996, 15, 17-34.

Bushek D. Dermo-disease in American oysters: genetics of host-parasite interactions. 1994, Ph.D. Dissertation. Rutgers, the State University of New Jersey, New Brunswick, New Jersey, 189 p.

Dungan C.F. \& Hamilton R.M. Use of tetrazolium-based cell proliferation assay to measure effects of in vitro conditions on Perkinsus marinus (Apicomplexa) proliferation. Journal of Eukaryotic Microbiology, 1995, 42, 379-388.

Faisal M., Shafhauser D.Y. \& La Peyre J.F. Purification of serine proteases from Perkinsus marinus using bacitracinsepharose affinity chromatography. Aquaculture'95, February 1-4, 1995, San Diego, CA, Book of Abstracts p. 108.

Faisal M., Kaattari S.L. \& La Peyre J.F. Extracellular proteins from Perkinsus marinus: analysis of pathogenic mechanisms and development of enhanced diagnostics. Final Report. National Oceanic \& Atmospheric Administration, National Marine Fisheries Service, Chesapeake Bay office, Annapolis, Maryland, $101 \mathrm{p}$.

FORD S.E. Range extension by the oyster parasite Perkinsus marinus into the northeast United States: a response to climate change? Journal of Shellfish Research, 1996, 15, 4556

Gauthier J.D. \& VASTA G.R. Continuous in vitro culture of the eastern oyster parasite Perkinsus marinus. Journal of Invertebrate Pathology, 1993, 62, 321-323.

Gauthier J.D., Feig B. \& Vasta G.R. Effect of bovine serum glycoproteins on the in vitro proliferation of the oyster parasite Perkinsus marinus: development of a fully defined medium. Jounal of Eukaryotic Microbiology, 1995, 42, 307313.

Kerridge D. \& Vanden Bossche H. Drug discovery: a Biochemist's approach, in: Chemotherapy of Fungal Diseases, Ryley J.F. (ed.), Springer-Verlag, Handbook of Experimental Pharmacology, Vol. 96, 31-76.
KLeinschuster S.J. \& Swink S.L. A simple method for the in vitro culture of Perkinsus marinus. The Nautilus, 1993, 107, 76-78.

La Peyre J.F. Propagation and in vitro studies of Perkinsus marinus. Journal of Shellfish Research, 1996, 15, 89-101.

La Peyre J.F. \& Chu F.L.E. A simple procedure for the isolation of Perkinsus marinus merozoites, a pathogen of the eastern oyster, Crassotrea virginica. Bulletin of the European Association of Fish Pathologists, 1994, 14, 101-103.

La Peyre J.F. \& Faisal M. Improved method for the initiation of continuous cultures of the oyster pathogen Perkinsus marinus (Apicomplexa). Transactions of the American Fisheries Society, 1995, 124, 144-146.

La Peyre J.F \& Faisal M. Perkinsus marinus produces extracellular proteolytic factor(s) in vitro. Bulletin of the European Association of Fish Patbologists, 1995, 15, 28-31.

La Peyre J.F \& Faisal M. Optimal culture conditions for the propagation of the oyster pathogen Perkinsus marinus (Apicomplexa) in protein deficient medium. Parasite, 1996, 3, 147-153.

La Peyre J.F., Faisal M. \& Burreson E.M. In vitro propagation of the protozoan Perkinsus marinus, a pathogen of the eastern oyster, Crassostrea virginica. Journal of Eukaryotic Microbiology, 1993, 40, 304-310.

La Peyre J.F., Schafhauser D.Y., Rizkalla E.H. \& Faisal M. Production of serine proteases by the oyster pathogen Perkinsus marinus (Apicomplexa) in vitro. Journal of Eukaryotic Microbiology 1995, 42, 451-458.

Levine N.D. Perkinsus gen. n. and other new taxa in the protozoan phylum Apicomplexa. Journal of Parasitology, 1978, 64, 549.

Mackin J.G., Owen H.M \& Collier A. Preliminary note on the occurrence of a new protistan parasite, Dermocystidium marinum n. sp. in Crassostrea virginica (Gmelin). Science, 1950, 111, 326-329.

MAURER H.R. Towards serum-free chemically defined medium for mammalian cell culture, in: Animal Cell Culture, A Practical Approach, Freshney, R.I. (ed.), IRL Press at Oxford University Press, 1992, 15-46.

PERKIns F.O. Ultrastructure of vegetative stages in Labyrinthomyxa marina (= Dermocystidium marinum), a commercially significant pathogen. Journal of Invertebrate Pathology 1969, 13, 199-222.

Perkins F.O. Dermocystidium infection in oysters. Marine Fisheries Review, 1976, 38, 19-21.

RAY S.M. A culture technique for the diagnosis of infection with Dermocystidium marinum. Science, 1952, 116, 360361.

Ray S.M. Biological studies of Dermocystidium marinum. 1954, Rice Institute Pamphlet. Special Issue. The Rice Institute, Houston Texas, 114 p.

Soniat T.M. Epizootiology of Perkinsus marinus disease of eastern oysters in the Gulf of Mexico. Journal of Shellfish Research, 1996, 15, 35-43

Reçu le 6 mai 1996 Accepté le 9 octobre 1996 